\title{
0 granicach i przepaściach: dyskurs o górach i separacji na terenach objętych konfliktem etnicznym
}

\author{
DOI: 10.19195/2084-4107.11.16
}

\section{Do „Jagnięcia” czy do „Młyna”?}

Kto na przełomie wieków wybrał się do leżącej w Dolomitach wsi Campitello będącej podówczas najbardziej znaną miejscowością turystyczną w południowotyrolskiej dolinie Fassa, zastał tam dwa schroniska: „Lamm” („Agnello”), czyli „Jagnię”, i „Mühle” („Mulino”), czyli „Młyn”. Obydwa hotele, otoczone wspaniałym górskim pejzażem, do których od 1904 r. można było dotrzeć Wielką Drogą Dolomitów, służyły podróżnym z różnych krajów jako punkt wyjścia w leżące w okolicy pasma górskie. Decyzja co do wyboru miejsca na nocleg nie była taka prosta: Baedeker pisał o dobrej sławie, jaką cieszył się „Młyn”, podczas gdy Club Alpin Français uważał go za ledwie zadowalający, a Niemiecki i Austriacki Związek Alpejski (DuÖAV) wręcz wniósł skargę na gospodarza oszukującego podobno gości. Z kolei „Jagnię” — hotel określany w Baedekerze jako „prosty” - Szwajcarski Klub Alpejski uznał za „wyśmienity”, chwaląc szczególnie tamtejsze risotto i muskatellera ${ }^{1}$.

Dokąd więc: do „Jagnięcia” czy do „Młyna”? Wilhelm Rohmeder, jedna z najważniejszych postaci ludowych organizacji obronnych, na którym nie robiła wrażenia ani sztuka kulinarna, ani też zalecenia Baedekera, nie miał wątpliwości: niemiecki podróżny zatrzymywał się w „Młynie”, a to ze względu na przyjazne Niemcom zachowanie gospodarza i jego personelu. „Jagnię” z zasady zaś należało unikać ze względu na właściciela sympatyzującego z włosko-nacjonalistycznymi kręgami w Południowym Tyrolu. Tego rodzaju wskazówek i informacji o hotelach i gospodach leżących wzdłuż tyrolskiej granicy językowej udzielał Rohmeder od 1903 r. co roku na początku sezonu letniego w radykalnie nacjonalistycznym piśmie „Alldeutsche Blätter”2.

${ }^{1}$ Aus Campitello 1898, s. 183; Baedekers Südbayern 1910, s. 446; Giraud 1908, s. 91; Täuber 1908/1909, s. 96.

2 Najpierw jako Rohmeder 1903; potem corocznie do 1910 r. Również publicysta i regionalista południowo-tyrolski o niemiecko-ludowej orientacji Karl Felix Wolff (1879-1966) stał na stanowisku, że „zrozumiałym jest oczekiwać od niemieckich turystów, że będą preferować gospody należące do nastawionych proniemiecko Ladynów", Wolff 1908, s. 271. Latem 1908 r. sekcje DuÖAV mające siedzibę na obszarze słoweńskim tudzież na granicznych terenach niemiecko-słoweńskich, a także Austriacki Klub Turystyczny wystosowały do „szacownych siostrzanych sekcji” prośbę, aby „W przyszłości (podobnie jak to już czyni Sekcja Bozen) [...] zalecały swoim członkom przedkładanie ponad inne schronisk, dróg i przewodników naszego Związku Alpejskiego, a także niemieckich i przyjaznych Niemcom gospód w czasie podróży w rejony granic językowych w Tyrolu, Karyntii, Krainie, Styrii i Pobrzeżu”, zob.: Archiwum Austriackiego Związku Alpejskiego, Innsbruck (odtąd: 
Raczej pewne jest, że autor niniejszych porad omijał szerokim łukiem „Jagnię" i serwowanego tam muskatellera. Czy można było jednak oczekiwać tego samego od niemieckiego urlopowicza? Czy i on wiedziony „narodowym imperatywem" miał się pozbawiać rozkoszy podniebienia? Czy można było podporządkować czas wolny i turystykę abstrakcyjnym etnicznym zasadom lojalności? Czy udało się zniwelować rozdział sfery prywatnej od publicznej, czyniąc z turysty aktywistę „sprawy narodowej”? Należy w to wątpić. Równie uprawnione jest jednak wątpienie w to, że ludowi bojownicy w rodzaju Wilhelma Rohmedera liczyli na bezpośrednie efekty swojej agitacji. Jakie zamiary kryły się więc za tymi inicjatywami?

Najpierw należałoby zadać pytanie o wiele bardziej zasadnicze, a mianowicie dlaczego nacjonalistyczne elity od późnego wieku XIX w ogóle upatrywały w społecznym ruchu turystycznym pola do działalności politycznej — pola, którego skuteczna instrumentalizacja zakładała wielokrotnie konceptualizację i internalizację nowych wizerunków tożsamości oraz struktur lojalnościowych. Patrząc z tej perspektywy, należy przyjrzeć się strategiom i procesom, które posłużyły kręgom nacjonalistycznym różnych grup etnicznych do stworzenia na nowo wzorców lojalnościowych i „map kognitywnych”.

W badaniach nad nacjonalizmem panuje zgodność co do postrzegania budowy tożsamości narodowych jako projektu społecznej i kulturowej integracji, w której konstruowanie przeciwstawień wyprowadza się z ,języka”, ,czasu” i ,przestrzeni”. Funkcjonalne okazały się w tym dyskursie tożsamościowym wyobrażenia „,natury” i „krajobrazu” podlegające również „nacjonalizacji”, symbolicznemu zajęciu i przypisaniu wyimaginowanych znaczeń. Jak doszło więc do narodowego zdobycia krajobrazu? Jakie pojawiły się nowe cele podróży i jaką funkcję symboliczną tudzież dyskursywną przypisano im w ramach identity tourism ${ }^{3}$ ? Jaki przyczynek wniosła i jakim przemianom podlegała literatura podróżnicza? Jaką rolę odgrywały w etnicznym procesie kształtowania świadomości kampanie publicystyczne i reklamowe zachęcające do odwiedzania obszarów granicznych i obszarów irredenty?

Upolitycznienie podróży było, jak dotąd, rzadko 4 przedmiotem zainteresowań historiograficznych — zainteresowania badaczy dotyczyły tu w pierwszym rzędzie instrumentalizacji turystyki w europejskich dyktaturach XX w. Także badania nad identity tourism dotyczą raczej późniejszych czasów oraz kontekstów politycznych i społeczno-ekonomicznych ${ }^{5}$ różniących się zasadniczo od panujących w późnym Państwie Habsburskim (badanym tutaj przede wszystkim na przykładzie Tyrolu).

AÖAV): Sekcja Kraina (252.1008): Apel „Szacowne sekcje siostrzane” (podpisano Josef Aichinger), Villach, lato 1908; przedtem już: AÖAV: Sekcja Krain (252.102): apel DuÖAV, Sekcje Krain i Cilli „Do szacownych sekcji siostrzanych!”, Ljubljana-Celje, grudzień 1903.

3 Pitchford 2008, s. 3.

${ }^{4}$ Por. przemyślenia Pietera M. Judsona w różnych publikacjach: Judson 2001a; Judson 2001b; Judson 2002; Judson 2005; Judson 2007; Judson 2011; też: Leoni 1989; Leoni 1990; Wedekind 1995; Wedekind 2000.

5 Na temat Szkocji zob. Grenier 2005; Walii: Pitchford 2008; USA: Shaffer 2001. 


\section{Urlopy na froncie}

Naznaczone etnicznie konflikty monarchii naddunajskiej o dostęp do surowców naturalnych, dochodów, gremiów decyzyjnych w polityce, dążenia do emancypacji i partycypacji nieniemieckich grup etnicznych doprowadziły do zacieśnienia przede wszystkim niemieckonarodowych kręgów wokół kolektywnego lęku przed ,wyparciem i ściśnięciem [...] przez inny naród" 6 . Zachwiana pewność siebie, defensywa społeczna i etniczna Niemców znajdują ujście w agresywnym i autorytarno-bojowym nacjonalizmie. Poprzez (nierzadko również biologistyczne) upostaciowienie narodu jako organizmu terytorialnego, który musi opierać się zewnętrznej presji demograficznej, granice językowe i „wyspy językowe” zostały emocjonalnie obciążone i przeciążone jako ,przyczółki niemieckości”, jako „główne linie walki” narodu. Stały się symbolicznymi miejscami inkluzji i ekskluzji, w których ,język” otrzymuje jako cechę dystynktywną plastyczność umożliwiającą ujrzenie i doświadczenie narodu. Wyobrażenie narodu wiązało się w sposób esencjonalny z wyobrażeniem jego granic ${ }^{7}$. Granice językowe i ,wyspy językowe” awansowały (w Tyrolu od późnych lat sześćdziesiątych XIX w.) do pola działań narodowych organizacji obronnych, stały się świadkiem politycznych potyczek z przeciwnikiem etnicznym, „murem chińskim nienawiści narodów" , jak to ujął w 1909 r. późniejszy premier Włoch, Alcide De Gasperi (1881-1954).

Na tle zaostrzającego się konfliktu narodowościowego w Tyrolu pojawiały się już od późnych lat siedemdziesiątych XIX w., szczególnie w Rzeszy Niemieckiej, apele dotyczące turystycznych odwiedzin spornych południowych obszarów granicy językowej. Ukazujący się w Gerze „Alpenfreund” nadał opublikowanemu w 1876 r. artykułowi tytuł: Narodowe zadania w czasie odwiedzin Tyrolu. W artykule tym wzywano do spędzania czasu w okolicach Bozen, Nonsberg, w Ladynii i wyspach językowych Górnych Włoch. Autor artykułu, Hans August Lotz (18331894), założyciel Niemieckiego Związku Szkolnego, wobec „doprawdy przerażającej ekspansji elementu romańskiego", a także wobec presumtywnego zaprzeczania niemieckich interesów przez administrację habsburską uważał za narodowy obowiązek poprzez ,intensywne ożywcze wizyty z Północy” uchować udręczonych mieszkańców terenów przygranicznych ,na ostatnich słonecznych południowych zboczach niemieckich Alp"9 przed italianizacją, a także przyczynić się do ich nobilitacji w sferze materialnej i duchowej. Podobne apele do podróżnych z rzeszy wilhelmińskiej odnoszące się do wzmacniania świadomości narodowej i obrony niemieckich interesów na terenach granicy językowej, a także dbałości o intencjo-

6 Mapperg 1876, s. 6.

7 Ta tematyka szczególnie w: Judson 2001a; Judson 2001b; ale także: Riederer 2007 oraz uwagi Pinwinklera 2003.

8 De Gasperi 1909; w oryginale włoskim: „le mura cinesi impastate di odio nazionale”.

9 Mapperg 1876, s. 7. 
nalną lojalność i związek z całym narodem można znaleźć w wielu późniejszych pismach niemieckich i austriackich organizacji związanych z obronnością ${ }^{10}$.

Gdy uzdrowiska i szczyty górskie stały się synonimem wypoczynku i rozrywki mieszczaństwa, niemieckie kręgi narodowe odkryły w sterowaniu turystyką oraz w nadaniu jej znaczenia politycznego potencjalny instrument ,zachowania, a nawet odzyskania"11 terenów leżących przy granicach etnicznych. Te nowe miejsca inscenizowane na lieux de memoire stanowiły często terrae incognitae na ówczesnych mapach europejskich celów podróży, zarówno odległe jak i trudno dostępne, a często pozbawione jakiejkolwiek infrastruktury turystycznej. Obrazki z podróży do np. ówczesnej włoskiej części Tyrolu wcale nie były zachęcające: jeszcze w drugiej połowie XIX w., podczas gdy rozwinięte już miejscowości turystyczne były przedstawiane w korzystny sposób, można znaleźć utyskiwania na zaniedbanie gospodarcze i społeczne dotyczące szczególnie ludności wiejskiej, skargi na niebezpieczeństwa czyhające na podróżnych, fatalne środki komunikacji i przerażające warunki noclegowe. Ciężko doświadczony w tym względzie niemiecki pisarz podróżnik z Monachium, Ludwig Steub (1812-1888), donosił w 1846 r. z dolin ladyńskich:

W Cortinie należy zatrzymać się u Pana Ghediny w Czarnym Orle. Jak na gospodę włoską jest on godny najwyższej pochwały. Jak to ma miejsce na całym obrzeżu językowym od Przełęczy Gotthard po Karyntię, gdzie po romańskiej stronie zatrudnia się niemiecką kelnerkę pełniącą rolę anioła czy też ducha porządku, tak jest i tutaj. Pod jej skrzydłami żyje się u Pana Ghediny całkiem czysto i smacznie. Jego gospoda jest ostatnim przyczółkiem niemieckiego komfortu w przeciwieństwie do łacińskiej rasy, która szczególnie w Cadore i Belluno zwraca uwagę brudem $^{12}$.

W ówczesnej niemieckiej literaturze podróży, którą często charakteryzuje spoglądanie z wyższością na południową stronę granicy językowej, postać miłującej porządek, energicznej i swobodnej pod wieloma względami niemiecko-tyrolskiej gospodyni i domesticité féminine urasta do konsolatoryjnego toposu ${ }^{13}$. „Kto wie - pisał »literacki odkrywca« Tyrolu Steub jeszcze wiele lat później - czy tam, w czystym powietrzu i wśród prostych ludzi, nie można się bawić równie dobrze i tak samo zdrowieć, jak wśród statecznych krynolin i bogato oprawionych uroczystości w Baden-Baden lub Interlaken!"14

Jednak te nowe cele podróży stosunkowo późno zostały opisane w uznanych przewodnikach. Baedeker poświęcał większe zainteresowanie wyspom językowym w Górnych Włoszech dopiero od przełomu wieków. Postulowane przez

10 Zob. Wedekind 2009, s. 84-88, szczególnie s. 88 (przyp. 16).

11 Mapperg 1876, s. 7.

12 Steub 1871, t. 2, s. 221.

13 Zob. np. Heyck 1911, s. 554; Lotz 1880, s. 35; Steub 1871, t. 3, s. 277-279; Steub 1889, s. 231.

14 Steub 1889, s. 231. 
Rohmedera stosowanie niemieckiej toponimii na całym obszarze Trydentu ${ }^{15}$ redakcja przejęła tylko w pojedynczych wypadkach; usunęła jednak nowe włoskie nazwy w Południowym Tyrolu. Wraz z opublikowanym jako „narodowy przewodnik" tomikiem oddziału Baden Niemieckiego Związku Szkolnegoo w centrum tradycyjnie apolitycznego gatunku znalazły się w roku 1900, po raz pierwszy w sposób wyraźny sformułowane, zupełnie nowe tematy (jak etniczny skład ludności i konflikty społeczno-ekonomiczne) $)^{17}$. Jeszcze silniej widać to w wydanym niewiele lat później Ludowym przewodniku po niemieckich osadach Południowej Austrii, w szczególności w „przewodniku” po mieszanej pod względem etnicznym południowej Karyntii ${ }^{18}$. Te wydawane przez komisję turystyki niemieckich radców ludowych przewodniki po krajach alpejskich autorstwa karynckiego aktywisty o orientacji wszechniemiecko-imperialistycznej, Ludwiga Jahne (1856-1937), przyczyniły się, wraz z budową schronisk i dróg przez Niemiecki i Austriacki Związek Alpejski, do wyparcia słoweńskiej, a upowszechnienia niemieckiej mikrotoponomastyki, szczególnie na obszarze Karawanków ${ }^{19}$.

15 Rohmeder 1898, s. VII.

16 Lusern 1900; Rohmeder 1901; Groos 1902; Groos 1908.

17 O funkcji przewodników jako medium mobilizacji narodowej zob. np.: Koshar 1998; w kontekście starego obszaru Tyrolu szczególnie: Bagnaresi/Wedekind 2011, s. 36-40 i passim.

18 Patrz: Jahne 1910; Jahne 1911; Jahne 1914, także Roschnik 1914, a po pierwszej wojnie światowej Jahne 1926.

19 Zob. też Veiter 1984, s. 461. Konflikt alpejsko-turystyczny pomiędzy niemieckim a słoweńskim mieszczaństwem do tej pory nie znalazł się w polu zainteresowań badawczych (tylko pewne wskazówki u Batagelj 2010, s. 134-139, Šaver 2005, s. 120-132), choć ich ostrość przewyższała konfrontacje mające miejsce w Tyrolu. Na o wiele mniej uczęszczanych słoweńskich terenach Alp w opozycji stały przede wszystkim założone w Ljubljanie Slovensko planinsko društvo mające 2662 członków i — popierane przez niektóre karynckie sekcje Związku Alpejskiego —— sekcje DuÖAV Krain (z siedzibą w Ljubljanie), Celje i Maribor liczące razem 621 członków (1913). Budowa schronisk i dróg alpejskich była tu postrzegana, jeszcze bardziej niż w Tyrolu, nie tylko jako wyraz narodowych roszczeń terytorialnych (ze strony słoweńskiej zwłaszcza jako środek zachowania „słoweńskiego charakteru” spornych gór), lecz również jako działanie konkurencyjne do niszczenia i bojkotu (po części skazanych na upadek) elementów turystycznej infrastruktury stworzonej w górach przez etnicznego przeciwnika. Członkowie DuÖAV widzieli we własnych schroniskach i drogach w dużym stopniu narzędzie językowego nasycenia przestrzeni, podczas gdy słoweńskie schroniska, z których pięć stało w bezpośrednim sąsiedztwie konkurencyjnych budynków, widziane były jako narodowe „reduty”. Słoweński Związek Alpejski natomiast traktował np. wzniesienie skromnego noclegowiska zwanego ,Aljažev stolp' (wieża Aljaža) zlecone prywatnie przez duchownego Jakoba Aljaža (1845-1927) w roku 1895 na będącej powodem waśni symbolicznej górze Triglav jako słoweński teren odzyskany, jako emancypację i koniec obcego stanowienia, ucisku, poniżenia i rozłamu; związek ten, który wcześnie zaczął podkreślać swoją istotną narodową rolę i poczucie misji (patrz np. Vdovič 1895) oświadczył w swoim biuletynie (Triglavska koča 1895): „To do nas Triglav należy i pozostanie nasz na wieczność!” (w oryginale słoweńskim: „Naš je Triglav in ostane naš na veke!"). Sekcja Krain DuÖAV skonstatowała natomiast dobre dziesięciolecie później, że to dopiero Słoweński Związek Alpejski „tak naprawdę zepchnął [ją] na pozycję niemiecką. Teraz $[\ldots]$ coraz bardziej widzimy nasz cel w przyciąganiu niemieckich podróżnych i wykorzystaniu płynących z tego pożytków, na ile to możliwe, dla siebie, to znaczy dla naszego związku jak i w ogóle dla Niemców i ich przyjaciół. Musimy przeciwstawiać się nieuczciwym sposobom

Góry, Literatura, Kultura 11, 2018

(C) for this edition by CNS 
Na terenie Tyrolu pozostającego pod wpływami włoskimi kręgi wszechniemieckie od 1905 r. zaczęły energiczniej starać się o mise en tourisme obszaru przy granicy językowej oraz o polityczną instrumentalizację turystyki. Przy poparciu Związku Wszechniemieckiego, Związku Granicy Południowej i Związku Niemców w Czechach specjalnie utworzone Monachijskie Towarzystwo Akcyjne nabyło z inicjatywy zorientowanego ludowo-antysemicko, a potem narodowo-socjalistycznie monachijskiego wydawcy Juliusa Friedricha Lehmanna (1864-1935) za 150000 koron podupadły zamek Pergine w Dolinie Sugana, a następnie pokaźne nieruchomości na zachodnim brzegu graniczącego z nią jeziora Caldonazzo oraz znaczną część samego jeziora. Teraz już jako „Burg Persen” zamek stał się hotelem dla zamożnych gości, którzy mogli zostać jego współwłaścicielami, „być w swoich narodowych poglądach zgodni i bliscy"20 i z zamku ,posłać śmiało swoje »Deutschland, Deutschland über alles« w ten zwłoszczony kraj”"21. Późniejszy kanclerz austriacki Michael Mayr (1864-1922), jedna z wiodących postaci niemiecko-narodowego Ludowego Związku Tyrolskiego, miał zaszczyt otworzyć w 1906 r. ten hotel, w którym prowokacyjnie umieszczono Salę Lutra. Później, dzięki finansowemu poparciu Niemieckiego Powszechnego Związku Szkolnego, również w Dolinie Fersina powstało kilka gospód, jednakowoż skromnych ${ }^{22}$. Natomiast nad jeziorem Caldonazzo otwierano kolejne niemieckie wille i pensjonaty $^{23}$.

Inicjatywa ta była związana $\mathrm{z}$ agresywnymi wszechniemieckimi planami germanizacyjnymi, które wychodząc z niemieckich wysp językowych i ladyńskich terenów osadniczych jako „przyczółków”24, przewidywały stopniowe zniemczenie terenów pomiędzy doliną Cembra i Luserną, a następnie wschodniej części kraju i reszty włoskojęzycznego Tyrolu. „Burg Persen” miał stać się przy tym bastionem i ,ostoją narodowego myślenia i działania” ${ }^{25}$, punktem wyjścia dla umocnienia i ,powrotnego zniemczenia” leżących niedaleko wysp językowych, dla przejścia „od obrony do ataku” ${ }^{26}$, punktem oparcia dla „,historycznie uzasadnionych i powstałych dzięki niemieckiej przewadze gospodarczej i turystyce wysuniętych placówek nad jeziorem Garda, w Dolinie Sugana itd."27 Podczas

traktowania nas, odpowiadać naciskiem na nacisk. Musimy dążyć do tego aby, na przekór konkurencyjnym schroniskom, członkowie naszego Związku Alpejskiego i w ogóle Niemcy odwiedzali wyłącznie nasze schroniska”, patrz AÖAV Sekcja Krain (252.1008): Zasady odporu Słoweńskiemu Związkowi Alpejskiemu Jesenic 31 maja 1908 (ściśle poufne!).

20 Lehmann 1935, s. 33; zob. też Burg Persen 1910; Mahr 1912.

21 Mahr 1912, s. 234.

22 Zob. Attività (bez roku wydania), 3. W roku 1905 w Florutz/Fierozzo powstała własna sekcja Niemieckiego i Austriackiego Związku Alpejskiego (Sekcja Niemcy-Fersental).

${ }^{23}$ Wśród nich znajdował się odwiedzany przez Zygmunta Freuda i węgierskiego psychoanalityka Sándora Ferencziego (1873-1933) „Seehof” w San Cristoforo al Lago, który powstał w roku 1909 z inicjatywy sekcji monachijskiej Związku Wszechniemieckiego.

24 Bartsch 1911, s. 205.

25 Fünfzig Jahre 1940, s. 165. Zob. też ironiczny przyczynek Baillie-Grohman 1920, s. 376.

26 Mahr 1912, s. 247.

27 Lukas 1927, s. 365. 
pierwszej wojny światowej Tyrolski Związek Ludowy zradykalizował swój program, dążąc do szybkiego i trwałego zniemczenia Trydentu. W swym katalogu mających temu służyć środków — zawierającym również inicjatywy osiedleńcze — współzałożyciel Związku Edgar Meyer (1853-1925) przypisywał istotną rolę kierowaniu strumienia turystów oraz subwencji do „niemiecko zorientowanych” zakładów hotelarskich ${ }^{28}$.

Jak pokazuje przykład ,Burg Persen', hotele i schroniska alpejskie stały się częścią semiotycznego systemu roszczeń terytorialnych ${ }^{29}$, obciążonego symboliką narodową, która znajdowała wyraz w architekturze, wnętrzach i nazewnictwie ${ }^{30}$. Jednocześnie przypisywano im strategiczną funkcję w przenikaniu i narodowej „okupacji” obcej etnicznie przestrzeni ${ }^{31}$. Tak, jak to było w wypadku renomo-

28 Meyer 1917, s. 11-12: „Dużą rolę w pokojowym zniemczaniu odegrać może turystyka. Bardziej niż kiedykolwiek turyści będą pochodzić z Austrii i z Rzeszy Niemieckiej. Wspierając ruch turystyczny w przebogatym w uroki natury Tyrolu Południowym, popierając a może i subwencjonując niemieckie gospody, pomagając jeszcze bardziej Niemieckiemu i Austriackiemu Związkowi Alpejskiemu można bardzo przyczynić się do zniemczenia.”

${ }_{29}$ Znamienne są tu poglądy panujące w kręgach przewodników trydenckiego Alpenclubu: „Che cosa rappresenta la SAT in alta montagna? Una accolta di alpinisti, o forse il Trentino di fronte al forestiero? L'una e l'altro ma anche qualche cosa di più: la Nazione Italiana. [...] [di fronte ai rifugi della SAT] non solo il forestiero debba dichiararsi contento delle comodità offertegli da noi italiani, ma lo stesso riconosca nella sua razza una certa vigoria, debba un po' insuperbire di quanto seppero fare i suoi connazionali, e quindi guadagnare nel sentimento nazionale", Fondazione Museo Storico del Trentino, Trydent: Archivio Cesare Battisti, karton 20, fascykuł 1: Pismo Guido Maestranzisiego i Vittorio Stenicosa do członków SAT, Trydent, 28.2.1910.

${ }^{30}$ Urządzony w stylu gotyckim hotel „Burg Persen” oferował gościom gotycką atmosferę uważaną za typowo niemiecką i narodową. Natomiast na przełęczy Pellegrino na wysokości 1900 m n.p.m. hotel ,Monzoni' demonstrował swoimi pomalowanymi w trzy kolory okiennicami włoskie uczucia narodowe. Jako demonstrowanie bez ogródek programu politycznego należało rozumieć nazwę hotelu „Dante Aligjieri” w Madonna di Campiglio będącego w posiadaniu spadkobierców Giovanniego Battisty Righi (1830-1882), pioniera lokalnego ruchu turystycznego. W pewnym sensie stanowił on wyzwanie dla tamtejszych niemieckich lokali, takich jak prowadzone przez Franza Josefa Oesterreichera (1848-1909) i utrzymane w żółtych barwach przypominających pałac Schönbrunn hotele „Carlo Magno” i „Des Alpes”. W „zatłoczonym zwykle w lipcu i sierpniu” hotelu „Des Alpes” (Baedekers Südbayern 1910, s. 411), w którym drobnomieszczaństwo czasów prosperity przemysłowej grzało się w blasku wizyt monarchii, przeżywając, choćby i chwilową, nobilitację i awans, jadano na wysokości 1515 m n.p.m. przy świetle elektrycznym pod freskami malarza z Bozen Gottfrieda Hofera (1858-1932) ukazującymi między innymi postacie Cesarza Franciszka Józefa (1830-1916) i Cesarzowej Elżbiety (1837-1898). W „Grand Hôtel Molveno” natomiast, który na Giovannim Pedrottim, jego duchowym twórcy i współfinansującym pozostawił deprymujące ,niemieckie wrażenie” (,impressione tedesca”, Fondazione Museo Storico del Trentino, Trydent: Fondo AL., karton 13, fascykuł 10: dziennik Giovanniego Pedrottiego, 20.8.1911.), ofertę kulinarną cechował pewien irredentystyczny posmak ceniony prawdopodobnie raczej przez gości a nie przez zatroskaną administrację austriacką (,minestrone alla genovese - Pesce di Molveno al naturale patatine di montagna, salsa milanese - Roastbeef alla piemontese") - co do politycznej funkcji ,staroniemieckiej izby' jako formy architektury wnętrz gastronomicznych; zob. Conrad 2012.

31 Zob. np. uwagi historyka z Trydentu Inama 1905: „La Méndola è ormai un lembo di suolo italiano che i tedeschi ci hanno tolto. Riconosciamolo rassegnati, e impariamo da questo fatto, che

Góry, Literatura, Kultura 11, 2018

(C) for this edition by CNS 
wanego eleganckiego hotelu „Victoria” w Bozen, lecz także w wypadku licznych hoteli na Mendel, a nawet drugorzędnych hoteli, jak np. „Buchholzer Hof” w pobliżu Salurn, przejście hotelu w posiadanie etnicznego przeciwnika traktowano jako „dokonanie wyłomu we froncie”, jego zakup zaś jako „podbój”32. W ten sposób dla Ettore Tolomei (1865-1955) i dla włoskich nacjonalistów tyrolskich skupionych wokół Emanuele Lanzerotti (1872-1955) okazją do świętowania stał się fakt, że udało się doprowadzić do przekazania Officine elettrico-industriali dell'Alta Anaunia zaopatrzenia w prąd hoteli na Mendel, a także kolejki na Mendel i Überetsch ${ }^{33}$. Gniewem uniosły się natomiast sfery włosko-nacjonalistyczne, gdy w 1895 r. pewne berlińskie towarzystwo przejęło źródła lecznicze Levico i Vetriolo, a dyrektor generalny tegoż towarzystwa, zaangażowany przedtem w organizację ruchu turystycznego na Sylt, Julius Adrian Pollacsek (1850-1921), wybudowawszy luksusowy Grand Hôtel z kąpieliskiem termalnym, a także utworzywszy park zdrojowy, przechadzał się po Levico: W obu uzdrowiskach „zaroi się w ciągu klilku lat od Niemców, a Włosi zostaną wymieceni” ${ }^{34}$.

Mniej więcej w tym samym czasie Wilhelm Rohmeder nawoływał w swoich informacjach o tyrolskich ,gospodach na granicach językowych, które można polecić niemieckim turystom" do bojkotu hotelarzy nieniemieckich lub o (do-

un popolo, non solo colle scuole e cogli asili, ma anche, e forse più, colle strade e cogli alberghi, può conquistare e conservare alla propria nazionalità, qualche tratto di suolo." - Podczas gdy niemiecko-narodowe organizacje obronne snuły plany zniemczenia Trydentu, w Południowym Tyrolu Ettore Tolomei widział w turystyce „[un] importante elemento nella gara delle influenze nazionali”, wzywał Włochów do odwiedzania tego kraju (Notizie alpine 1907, s. 239) i zdawał systematycznie relację z postępującego zagospodarowania turystycznego, powstawania nowych hoteli i schronisk, osiągnięć alpinistycznych i działalności organizacji alpejskich.

32 Hotel „Victoria” w Bozen przeszedł w posiadanie trydenckiego banku, podobnie „Buchholzer Hof” został przejęty w 1902 r. przez włoskiego właściciela. Hotel nieoczekiwanie zyskał niekorzystną opinię, a stało to się w chwili, gdy niemiecko-austriaccy aktywiści ludowi sądzili, że właśnie święcą sukcesy w zniemczeniu na powrót Południowego Tyrolu; patrz: Rohmeder 1903, s. 163; Attività (bez roku wydania), 7; De Gasperi 1909. Ze względu na krajobraz hotelowy na Mendel prezes sekcji Bozen Związku Południowogranicznego zażądał w 1914 r. założenia „banca propria per la difesa del territorio nazionale”. Jednocześnie żałował, że związek nie udaremnił zakupu hoteli ,Victoria', i ,Mendelhof' przez trydencki Banca cattolica; patrz: Biblioteca civica, G. Tartarotti', Roverto: Fondo „Manoscritti” 79.1 (39): Gabriela Bonora: la propaganda irredentista della Societa degli Alpinisti Tridentini, 1872-1915. Odnośnie konfliktów na Mendel wyczerpująco: Visintin 2012.

33 Patrz: Economia e politica 1907, s. 208.

34 Monteleone 1963, s. 9. Niemieckie przewodniki (Erler 1900, s. 8) dostrzegały w modernizacji Levico zarzewie konfliktu kulturowego: „Uzdrowisko Levico [...] miało złą reputację, jakoby zbyt mało dbano tam o potrzeby i przyzwyczajenia gości. Należy usprawiedliwić to faktem, że podówczas gros gości uzdrowiska stanowili Włosi z sąsiedniego królestwa i w związku z tym uwzględniano w pierwszym rzędzie ich pod wieloma względami specyficzne przyzwyczajenia. Od kiedy Levico zyskało dzięki nowym urządzeniom uzdrowiskowym w pełni międzynarodowy charakter, także w tym względzie podjęto szczęśliwie zmiany organizacyjne”. Niemiecki działacz narodowy, naukowiec, poeta i tyrolski wizytator szkolny Christian Schneller (1831-1908) miał nadzieję na językową ekspansję niemieckiego wskutek przybywania większej liczby niemieckich gości do Levico (Nequirito 1999, s. 107).

Góry, Literatura, Kultura 11, 2018

(C) for this edition by CNS 
mniemanej) orientacji włosko-narodowej. Taktyka doprowadzania etnicznych przeciwników do ruiny gospodarczej szybko znalazła naśladowców na innych terenach monarchii, a to dzięki wydawanemu w Innsbrucku wszechniemieckiemu tygodnikowi „Der Scherer”, a następnie od 1903 r. dzięki „Alldeutsche Blätter” uzupełnianym o broszury i różnego rodzaju austriackie gazety. Już w 1902 r. ukazujący się w Trydencie dziennik "Alto Adige” odparował cios, publikując listę ,włoskich” hoteli, podczas gdy komisja turystyczna niemieckich radców ludowych dla krajów alpejskich dostarczała od 1907 r. co roku spis przyjaznych Niemcom zakładów hotelowych w południowej Karyntii, Krainie, Dolnej Styrii, Pobrzeżu i Dalmacji ${ }^{35}$. Wezwania do bojkotu publikowane przez Rohmedera, które przyniosły skutki w postaci licytacji hoteli w Trydencie i $\mathrm{Arco}^{36}$, przysporzyły wkrótce pracy — jakkolwiek bez skutków — nie tylko sądom krajowym, lecz także samemu cesarsko-królewskiemu ministerstwu sprawiedliwości ${ }^{37}$. Już w 1903 r. magistrat miasta Trydent czuł się w obowiązku umieścić w ukazujących się w Rzeszy Niemieckiej gazetach sprostowanie odnoszące się do relacji w gazetach tyrolskich, w którym odradzano odwiedziny włoskiego Tyrolu, wskazując na konflikty etniczne ${ }^{38}$.

Przenoszenie etnicznych i rasowych wzorców segmentacji na sektor turystyczny $^{39}$, próby „nacjonalizacji” branży turystycznej oraz mobilizacji i kierowania strumieniem turystów trudno zmierzyć w kontekście ich realnego oddziaływania. Aktywista ruchu narodowego, Ludwig Jahne, wypowiadał się po pierwszej wojnie światowej bardzo sceptycznie o zasięgu działania tych środków,

35 Zob. spis 1909; też Rogy 1998, s. 497; Rogy 2002, s. 124-125.

36 Judson 2001a, s. 80.

37 Zob. Tiroler Landesarchiv, Innsbruck: K.k. Statthalterei-Präsidium für Tirol und Voralberg, 1909/1492: Rozporządzenie c.k. Ministerstwa Sprawiedliwości z 2 marca 1909, Z. 6861, do c.k. Prokuratury Krajowej Innsbruck.

38 Zob. Archivio storico del Comune di Trento, Trydent, Ordinamento austriaco, 1903, categoria XIII, fascykuł 45. Por. jednak też: Irredento 1913, s. 31: „[in Trentino, viaggiatori del Regno] corrono il pericolo 98 volte su cento di essere arrestati, o per lo meno molestati seriamente dalla polizia o dalla gendarmeria o dalle autorità militari. [...] Questo parrebbe dunque un ostacolo insormontabile alla venuta d'italiani liberi nel Trentino."

${ }^{39}$ Należy tu wspomnieć o rozpoczynającej się w późnym XIX w. dyskryminacji żydowskich turystów, która stała się znana pod nazwą ,,antysemityzmu letniskowego”, a w Austrii rozpowszechniona była przede wszystkim w Kitzbühel i Volderbad (Tyrol), Wald im Pinzgau (Salzburg), Einöd, Pöllau, Schladming i Tragöß (Styria), Wachau i w Galicji. W Południowym Tyrolu Rentsch i Bad Schalders określały się jako antysemickie miejscowości urlopowe. Również Oberbozen na Ritten, tradycyjne letnisko mieszczaństwa z Bozen, było polecane jako „czyste od Żydów”. W Bozen „wolny od Żydów” był „dobromieszczański” hotel „U olbrzyma”, w Gries gospoda — „Pod białą różąa”, w Seis am Schlern — „Dolomitenhof”. Tym samym wyznacznikiem reklamowały się również hotele w Innsbrucku (Hotel „Kreid”, „U czerwonego Orła”, „U białego krzyża”, w Kufstein i Mühlgraben (Tyrol), Schärding (Górna Austria), jak i liczne hotele w Karlsbad. Patrz: Uzdrowiska wolne od Żydów, 1912 (za wskazanie tej publikacji dziękuję Matthiasowi Viglowi, Wiedeń); Bajohr 2003. W Trydencie Emanuele Lanzerotti łączył rosnącą prezencję Niemców i Austriaków w przemyśle turystycznym z troską o znaczący przypływ „,[di] tedeschi, ed ebrei tedeschi più o meno colti, ricchi o speculatori”; Lanzerotti 1914, s. 22-23. 
patrząc na stanowczo słabiej, w porównaniu z Tyrolem, odwiedzane tereny Alp Julijskich, Karawanków, Alp Kamnickich i Santalskich ${ }^{40}$, zaś austriacki statystyk i badacz finansów Richard Pfaundler (1882-1959), który zajmował się przede wszystkim kwestiami statystyki narodów, rozwoju ludności i historycznego przebiegu niemieckiej granicy językowej na terenie Wschodnich Alp, wskazywał w 1908 r. na to ${ }^{41}$, że cztery piąte gości zarejestrowanych w mieszanych etnicznie księstwach Tyrolu, Karyntii i Styrii było turystami z Austrii i Rzeszy Niemieckiej. Ze względu na to można odnotować wzrost znajomości niemieckiego w dolinach ladyńskich, w Fleimstal/Val di Fiemme, na zachodnim brzegu jeziora Garda, jak i w Karawankach oraz w Alpach Kamnickich i Santalskich. Rosnący ruch turystyczny doprowadził do powstania ,niemieckich kolonii” w Riva, Arco, Salò i Gardone, w Gröden, a także w uzdrowiskach dzisiejszej Słowenii (Rogaška Slatina, Rimske Toplice i Dobrna pod Celje), podczas gdy słoweńska ludność wokół jeziora Wörthersee została w poważnym stopniu ,zniemczona”. Domniemane umocnienie przygranicznej ludności niemieckiej w kontekście ekonomicznym i narodowym poprzez rozwój turystyki i jej denacjonalizujące efekty uboczne kazały Pfaundlerowi przypomnieć, aby przy dalszej rozbudowie lokalnej sieci kolejowej (jak kolej fleimstalska) brać pod uwagę strategiczne punkty widzenia związane z polityką narodową.

\section{Syndromy duszenia się}

W ostatnich dziesięcioleciach XIX w. południowa, włoskojęzyczna część Tyrolu nie była już ,terra incognita w najpełniejszym tego słowa znaczeniu”42, jak ją jeszcze w 1862 r. opisał pochodzący z Meranu Rochus Perkmann (1830-1899), wiedeński profesor geografii i statystyki. Po początkach turystyki uzdrowiskowej (przede wszystkim w Levico, Rabbi, Arco i Riva) oraz po powstaniu pierwszych alpejskich letnisk (w Madonna di Campiglio i San Martino di Castrozza) w latach sześćdziesiątych i wczesnych siedemdziesiątych region Trydentu otworzył się ledwie dziesięć lat później także na turystykę górską ${ }^{43}$. Organizacje alpejskie, turystyczne i lokalne towarzystwa upiększania ${ }^{44}$ wspierały ten rozwój, jakkolwiek pozostał on w kontekście dynamiki wzrostu daleko za innymi krajami monarchii.

40 O odwiedzinach południowych Alp Wapiennych 1925, 2001.

41 Pfaundler 1908.

42 Perkmann 1862, s. VII.

$43 \mathrm{Na}$ temat historii turystyki w rejonie Trydentu zob. Bertoldi 1958, Bonoldi 2003, Leidlmair 1988, Leonardi 2009.

44 Wśród nich znalazło się Società degli Alpinisti Tridentini, założone w 1890 r. przez izbę handlowo rzemieślniczą Rovereto i związane na różne sposoby z organizacjami o orientacji narodowej Società per l'incremento del concorso di forestieri nel Trentino, jak i różne Società di abbellimento. 
Nie ziściła się również nadzieja na zaabsorbowanie przez romańsko-tyrolski przemysł turystyczny znacznej części gości napływających do Szwajcarii ${ }^{45}$.

Wprawdzie w latach belle époque udało się zwiększyć liczbę odwiedzających; jednak biorąc pod uwagę gości przybywających do całego Tyrolu, tylko 16\% przypadało na przełomie wieków na włoską część kraju. Jakkolwiek liczba turystów wzrosła tam pomiędzy rokiem 1890 a 1910 ponad sześciokrotnie do niemal 160000 rocznie, nie mogło się to równać z tendencją wzrostową w niemieckojęzycznym Tyrolu, gdzie w tym samym czasie liczba gości wzrosła czterokrotnie, osiągając 740 000. W ten sposób cały Tyrol mógł krótko po przełomie wieków pozbawić Czechy pierwszeństwa wśród najczęściej odwiedzanych uzdrowiskowych księstw monarchii; jednak czymże były te liczby wobec tamtych czterech milionów gości, którzy w samym tylko 1911 r. odwiedzili brytyjski kurort nadmorski Blackpool? ${ }^{46}$

Porównywalnie niewielki pozostawał również udział regionu trydenckiego w rocznych obrotach związanych z turystyką w całym Tyrolu; w roku 1890 stanowił on $20 \%$ (odpowiednio 2,8 miliona koron) ${ }^{47}$. Spojrzenie na liczby dotyczące zatrudnienia w branży hotelowej i turystycznej ukazuje podobny obraz: nawet w roku 1910 tylko 13\% ze wszystkich 9400 zatrudnionych przypadało na okręg izby handlowo-rzemieślniczej Rovereto, zaś w okręgach Innsbruck i Bozen było to odpowiednio 39\%, względnie 48\% ${ }^{48}$. Ogólnie zwiększenie potencjału sektora terytorialnego (a w szczególności rosnącego przemysłu turystycznego ${ }^{49} \mathrm{~W}$ związku z komplementarnym otwarciem komunikacyjnym prowincji poprzez budowę lokalnych kolei), mające nastąpić na drodze zasadniczej modernizacji społeczno-ekonomicznej, do którego dążyły przede wszystkim liberalne siły reformatorskie w Trydencie, nie ziściło się w oczekiwanym wymiarze.

Jednocześnie jednak można było odnotować znaczące związki trydenckiego przemysłu turystycznego z kapitałem niemieckim, szczególnie na Mendel, w Madonna di Campiglio, Arco, Levico i San Martino di Castrozza. W latach poprzedzających pierwszą wojnę światową 37 znaczących hoteli we włoskiej części Tyrolu było w posiadaniu niemiecko-austriackim ${ }^{50}$. Jeśli chodzi o schroniska alpejskie z ich wysoką semiotyczną walencją, w południowej części kraju naprzeciw 20 schronisk Trydenckiego Klubu Alpejskiego (Società degli Alpinisti Tridentini; SAT) stało w końcu 12 schronisk Niemieckiego i Austriackiego

45 Zob. Tomaschek von Stratowa 1894, s. 39.

46 Walton 2000, s. 52.

47 Scotoni 1913, s. 60. Z 14 milionów koron 1,9 przekazano starostwu powiatowemu Riva i przykładowo 4,3 mln starostwu powiatowemu Meran.

48 Meixner 1992.

49 Zob. Wedekind 2005.

50 Gayda 1914, s. 440-441. Spośród 37 wymienionych hoteli siedem znajdowało się w Arco (,infestata da sanatori germanici”, Manzi 1915, 376), po pięć w Riva i w Trydencie, po trzy w Madonna di Campiglio i na Mendel, po dwa w Levico, San Martino di Castrozza, San Cristoforo i Torbole, po jednym w Canazei, Paneveggio, Pergine, Rovereto jak i na przełęczach Fedaia i Pordoi. W kwestii Arco zob. Grazioli 1996, s. 236. 
Związku Alpejskiego ${ }^{51}$. Ponadto do wybuchu wojny sama liczba gości z wilhelmińskich Niemiec przekroczyła liczbę turystów włoskich o 30\%. Wprawdzie Levico i większość mniejszych uzdrowisk (jak Roncegno, Vetriolo, Rabbi, Peio i Comano), podobnie jak wiele letnisk, odwiedzali w przeważającej liczbie goście włoscy, lecz w obleganych kurortach Riva i Arco oraz w sektorze turystyki górskiej przeważali podróżni z krajów niemieckojęzycznych ${ }^{52}$. Dominacja turystów alpejskich z zagranicy, na którą kręgi narodowe uskarżały się po raz pierwszy już w latach siedemdziesiątych, nie uległa zmianie w kolejnych dziesięcioleciach: w ruchu odwiedzających schroniska SAT pomiędzy rokiem 1881 a 1903 goście niemieccy mieli udział $65 \%$, podczas gdy goście włoscy stanowili ledwie $32 \% 53$.

W wywodzących się głównie z mieszczaństwa nacjonalistyczno-irredentystycznych kręgach Trydentu rozwój ten był postrzegany jako wyprzedaż ojczyzny, jako inwazja i upokorzenie, jako zalanie obcym żywiołem i germanizacja ${ }^{54}$. Mieszczanie niemieccy, zwłaszcza z Rzeszy, stanowili tu od wczesnych lat siedemdziesiątych ambiwalentny wzorzec, będąc zarówno obiektem naśladownictwa, jak i inwektyw. Z podziwem nad kulturalno-naukowymi, społecznymi i gospodarczymi standardami cesarskich Niemiec mieszała się frustracja mająca korzenie w dostrzeżeniu różnicy między tymi standardami a własną rzeczywistością społeczno-ekonomiczną i — w odróżnieniu od Rzeszy Niemieckiej - niedoskonałym włoskim państwem narodowym, jednocześnie jednak także strach przed potencjałem władzy i zjadliwością niemieckiego nacjonalizmu. Poczucie izolacji i interioryzacji, niekiedy graniczący z fobią strach przed przewaga obcego etnicznie elementu oraz przyjęcie postawy, wedle której konieczne jest egzekwowanie swoich praw, stały się we włoskim Tyrolu od roku 1866 stałymi elementami kolektywnego samopoczucia obozu mieszczańsko-narodowego. Jego nacjonalizm był w pewnym sensie asynchroniczny względem nacjonalizmu austriackiego/niemieckiego, lecz podobnie jak ten ostatni — uwikłany w dylemat bezpieczeństwa.

Powtarzające się nawoływania o wzmożone odwiedzanie rodzimych gór nie odniosły skutku, tak jak etnocentryczne kampanie reklamowe kierowane do pu-

51 Zob. Wedekind 1995, s. 72. Spośród schronisk SAT trzy znajdowały się w Dolomitach, 14 zaś w zachodnich grupach górskich Trydentu (Ortler, Presanella, Adamello i Brenta). Niemiecki i Austriacki Związek Alpejski dysponował natomiast w Dolomitach ośmioma, a w górach zachodniego Trydentu dwoma schroniskami.

52 Zob. Tomaschek von Stratowa 1894. W pierwszym statystycznym ujęciu ruchu turystycznego w Austrii w roku 1892 odnotowano następujące liczby gości: Riva 4310, Trydent 3038, Arco 2039, Levico 2020, Ruffré 1216, Borgo Valsugana 1120, Roncegno 864, Vetriolo 676, Dimaro 666, Rabbi 640; Bozen 21 724, Zwölfmalgreien 2442, Gries 1873, Meran 6275, Toblach 5438, Cortina d'Ampezzo 5408, Bruneck 2638, Brixen 2168; Innsbruck 46 528; Salzburg 50 955; Karlowe Wary 38 271, Riva 4310, Trydent 3038.

53 Pedrotti 1903/1904, s. 152 nn.

54 Zob. Alcuni cenni 1912, s. 36; Lanzerotti 1914, s. 22-23. 
bliczności we Włoszech ${ }^{55}$. Kampanie te były inicjowane mniej więcej od roku 1903 z poparciem Cesare Battisti (1875-1916) pod hasłem „Italiani, visitate il Trentino!” przede wszystkim przez lokalny klub alpejski i towarzystwo wspierania turystyki we współpracy z kręgami irredentystycznymi w Mediolanie i posługiwały się po części również fotografią i filmem jako środkami propagandowymi ${ }^{56}$.

Wprawdzie już przed przełomem wieków Società Nazionale Dante Alighieri, dotując w znaczący sposób związek obronny Lega Nazionale w sąsiednich Austro-Węgrzech, starała się popierać wizyty Włochów na terenach irredenty, a jednocześnie w odpowiedzi na rozumiane jako „system placówek wysuniętych" hotele będące w posiadaniu niemieckim, budować własne hotele; jednak przedsięwzięcie to nie powiodło się m.in. ze względu na odmienne koncepcje strategiczne: w 1899 r. lokalne kręgi nacjonalistyczne skupione wokół Guglielmo Ranzi (1859-1932) odrzuciły pomysł inicjowanej przez Towarzystwo im. Dantego Alighieri budowy mającego nosić symboliczne znaczenie Grand Hotelu w Trydencie na rzecz przynoszącego większe zyski hotelu górskiego będącego znakiem narodowych roszczeń terytorialnych ${ }^{57}$. Do realizacji przedsięwzięcia doszło dopiero kilka lat później w ramach planu działań zakładającego udaremnienie budowy kolejnych niemieckich/austriackich hoteli i schronisk poprzez wykup ziemi w turystycznie atrakcyjnych, położonych wysoko w górach miejscach regionu trydenckiego przez Włochów. Societa per Alberghi Alpini wzorowana była na organizacjach południowo-tyrolskich przy udziale kapitału przede wszystkim deponentów z Włoch. Jej celem było wznoszenie budowli nie tylko w Dolomitach (na przełęczach Sella, Pordoi, Fedaia, San Pellegrino i Lusia), lecz i w Masywie Brenta — ,jedynym nie należącym do nas masywie"58 — jak formułowano skar-

55 Wyjątek stanowiły podejmowane nierzadko z irredentystycznej inspiracji wycieczki z włoskich portów nad jeziorem Garda do austriackiego Riva. Jeśli doliczyć do tych wypadów gości przybywających statkami liniowymi, to wycieczki te prowadziły w weekendy do 500 odwiedzających z Górnych Włoch do miasta. Na ,podniosły nastrój” wycieczkowiczów oraz ich okazjonalne manifestacje i prowokacje nerwowa administracja habsburska reagowała licznymi zakazami, jak np. zakazem występowania umundurowanych włoskich zespołów muzycznych. O jednej z takich wycieczek starostwo powiatowe Riva donosiło oddziałowi namiestniczemu w Trydencie pod datą 31.7.1888.: „Tenże [zespół muzyczny z Maderno] przybył tu rzeczywiście w cywilnym stroju i, zdeponowawszy instrumenty na statku, wyszedł na ląd, jak i pozostali odwiedzający, w sposób najzupełniej prywatny. Pobyt towarzystwa tego przebiegał bez najmniejszych zakłóceń, a gdy nadszedł czas odjazdu i wszyscy już byli na statku, zespół muzyczny, o którym tu mowa, zaprezentował się nagle na górnym pokładzie w pełnym umundurowaniu, zaintonował tzw. „Marcia reale”, przy którego dźwiękach statek opuścił port”, Archivio di Stato di Trento: Sezione di Luogotenenza di Trento, Presidiali, 1888, karton 123, fascykuł D 171888.

56 Zob. np. Gita 1901, s. 263; Italiani (bez roku wydania), 1-2; Italiani 1907.

57 Zob. Fondazione Museo Storico del Trentino, Trient: Archivio Guglielmo Ranzi, karton 1, fascykuł 2, arkusz 28-29 i 40.

58 Fondazione Museo Storico del Trentino, Trient: Archivio Cesare Battisti, Karton 20, Faszikel 1: pismo Guido Maestrazisiego i Vittorio Stenicosa do członków SAT, Trydent, 28.2.1910 (w oryginale włoskim: l'unico gruppo di monti nostro). Società per alberghi alpini czerpała z założonego w 1890 przez Theodora Christomannosa (1854-1911) Verein für Alpenhotels in Tirol (Stowarzyszenia hoteli alpejskich w Tyrolu).

Góry, Literatura, Kultura 11, 2018

(C) for this edition by CNS 
gę na silne zaangażowanie prywatnego kapitału niemieckiego, organizacji obronnych i alpinistycznych w turystyczne odkrycie i zagospodarowanie wschodnich części kraju. O ile przy budowie schronisk pomagały pojedyncze sekcje włoskiego Club Alpino Italiano (CAI), o tyle budowa większości tych hoteli i noclegowisk została zrealizowana dzięki wsparciu zamożnych mieszkańców miasta Trydent ${ }^{59}$. Tak, jak np. odwiedzany przez Zygmunta Freuda (1856-1939) i włoskiego pisarza Antonio Fogazzaro (1842-1911) ,Grand Hotel Molveno' — zbudowany w 1903 r. przez specjalnie założoną spółkę akcyjną — te lokale powstałe przed wybuchem wojny uchodziły za prestiżowe, istotne z narodowego punktu widzenia ,bastio$\mathrm{n}[\mathrm{y}]$ rodowitej łacińskości" 60 .

Podobnie, jak w analogicznych wyobrażeniach po stronie niemiecko-tyrolskiej, narodowe kręgi Trydentu widziały (ostatecznie na próżno werbowanego) turystę z Włoch przede wszystkim w specyficznej interakcji z host society: w służbie dyfuzji idei narodowej, intencjonalnej uniformizacji i wykształceniu kolektywnego etnocentrycznego poczucia tożsamości, w zmianie zorientowania lojalności politycznych. Cele te stały w sposób oczywisty w sprzeczności do argumentów ekonomicznych i zamiaru spotęgowania trydenckiego przemysłu turystycznego: to, że podróżnych ze środkowej Europy, w szczególności z Niemiec, nie da się zastąpić przez gości włoskich, okazało się najpóźniej w latach powojennych. Trydencki obóz nacjonalistyczny żył w dylemacie polegającym na tym, że jego etnocentryczne maksymy działania stały na przeszkodzie rozwojowi ekonomicznemu i modernizacji kraju.

\section{Zetnicyzowane krajobrazy, leisure spaces i laboratoria doświadczalne}

Instrumentalizacja i zetnicyzowanie społecznych, dalekich od polityki praktyk związanych ze sferą prywatną (turystyka, sport, alpinizm i temu podobne) mają korzenie w kompleksowej i niespójnej nacjonalizacji społeczeństw środkowoeuropejskich na przełomie XIX i XX w. W cislejtańskiej części monarchii habsburskiej proces ten przebiegał — inaczej niż np. w Niemczech, we Włoszech

59 Giovanni Pedrotti postawił w 1905 r. luksusowy ,Hotel Pordoi’ (w owym czasie najwyżej położony hotel w Alpach), przepisał w 1906 r. na własność SAT wcześniej nabytą nieruchomość na przełęczy Fedaia, gdzie organizacja otworzyła w 1908 r. ,Albergo Valentini’ (później „Rifugio Albergo Venezia'), a także wniósł znamienny wkład w budowę hotelu ,Monzoni' na przełęczy San Pellegrino. Wsparcie finansowe ze strony przedsiębiorców branży tekstylnej Giuseppe (1863-1937) i Carlo Garbari (1869-1937) umożliwiło budowę ,Rifugio Taramelli' (1904) oraz ,Rifugio Dodici Apostoli' (1908). Również po stronie Niemieckiego i Austriackiego Związku Alpejskiego budowa schronisk była częściowo finansowana przez zamożne osoby prywatne, wśród nich na obszarze Dolomitów Trydenckich ,Ostertag Hütte' południowo-tyrolskiej sekcji Welschnofen przez przemysłowca ze Stuttgartu Karla von Ostertag-Siegle (1860-1924).

${ }^{60}$ Inskrypcja na umieszczonej w 1921 r. na ,Hotel Molveno' tablicy pamiątkowej (w oryginale włoskim: ,propugnacolo dell'originaria latinità”). 
czy we Francji — w opozycji zarówno do modernizacji i centralizacji state building, jak i do starań o wzmocnienie zorientowanego dynastycznie patriotyzmu austriackiego. Proces nation building różnych grup etnicznych monarchii opierał się na siłach niemających dostępu do aparatu państwowego, a tym samym do klasycznych organów socjalizacji (instytucje oświatowe, wojsko i temu podobne), zmuszonych więc do posiłkowania się innymi środkami w celu socjalizowania narodowości. Bardzo istotna była tu funkcja zorientowanych narodowo organizacji o szerokim zasięgu, które wprawdzie zakotwiczone w środowisku miejskim, swój właściwy teren działania i misji znalazły na obszarze wiejskim o innej strukturze, szczególnie na granicach językowych i narodowych. Apel skierowany do warstwy niemieszczańskiej, szczególnie do warstw rolniczych, w których wielu wymykało się jednoznacznemu przypisaniu narodowemu, natrafił na poważne bariery komunikacyjne. Społeczny zasięg kręgów ludowych, ale także nacjonalistyczno-irredentystycznych, okazał się tu wyraźnie ograniczony ${ }^{61}$.

Obciążone semiotycznie, wyimaginowane linie, które miały pozwolić (w pewnym sensie z perspektywy granicznej) doświadczyć narodu, stały się celami turystycznymi ${ }^{62}$. Na ile narodowe projekty tożsamości ze swymi etnocentrycznymi interpretacjami i wyobrażeniami „natury”, „krajobrazu”, „kultury” czy „historii” odwoływały się do kategorii będących zarazem centralnymi elementami praktyk turystycznych, na tyle turystyka jawiła się jako przydatny środek internalizacji elementów narodowych w kontekstach związanych ze spędzaniem wolnego czasu: „Heritage became the locus where tourism and nationalism converged"63. Realistycznym celem lansowanych przez kręgi związane z organizacjami obronnymi etnocentrycznych nawoływań do bojkotu, apeli i turystycznych kampanii reklamowych nie mogło być na początku bezpośrednie oddziaływanie na zachowanie jednostki, lecz co najwyżej włączenie jej w społeczno-psychologiczne procesy socjalizowania narodowości. Nie chodziło tak bardzo o to, czy niemiecki gość zatrzyma się u „Jagnięcia”, czy też u „Młyna”, lecz o zakotwiczenie projektów tożsamości i konstruktów granic etniczno-kulturowych, o uświadomienie presumtywnych roszczeń terytorialnych i egzogenicznych potencjałów zagrożenia, o terytorializację narodu.

Poza semantyczną i symboliczną „okupacją” licznych przestrzeni i wpisaniem ich w topografię miejsc kształtowania świadomości narodowej (np. poprzez rytualne, wzmacniające wspólnotę obchodzenie uroczystości) kreowano projekty przeciwstawne do utrwalonych map mentalnych oraz nowe kolektywne percepcje przestrzeni i krajobrazu. Cytując Simona Schama, można stwierdzić, że

[that] inherited landscape myths and memories share two common characteristics: their surprising endurance through the centuries and their power to shape institutions that we still live with. National identity [...]

\footnotetext{
61 Zob. Wedekind 2005, s. 83-84; Judson 2006.

62 Zob. Judson 2001a, s. 65.

63 Winiwarter 2008, s. 206.
} 
would lose much of its ferocious enchantment without the mystique of a particular landscape tradition: its topography mapped, elaborated, and enriched as a homeland ${ }^{64}$.

U podłoża tych wyniesionych przez kręgi nacjonalistyczne do swoistego znaku firmowego i reklamowanych turystycznie projektów przestrzennych leżały sprzężone z całym narodem, odnoszące się wszędzie do obszarów granicznych, scenariusze zagrożeń.

Przy tym w wypadku Tyrolu zachodziła wyraźna różnica pomiędzy niemiecko- i włoskojęzyczną częścią kraju: nacjonalistyczne kręgi Trydentu widziały, w nawiązaniu do poglądów rozwijanych we włoskiej historiografii od wczesnego XIX w., punkt odniesienia w średniowiecznych włoskich miastach republikach, a przestrzeń miejską jako punkt wyjścia i innowacji dla rozwoju politycznego i społecznego, jako ,principio ideale delle istorie italiane"65, a nawet jako „molla [...] reale, solida, attiva e permanente del vivo e sicuro patriottismo"66. Włoskim kręgom związanym z organizacjami obronnymi, które wywodziły się niemal wyłącznie ze społeczności mieszczańskiej, zachowywały jej kulturę i normy, nie udało się - inaczej niż niemiecko-austriackim kontrahentom - stworzyć projektu ,zetnicyzowanych krajobrazów”, który miałyby rzeczywistą siłę oddziaływania ${ }^{67}$. Mieszczaństwo trydenckie odbierało zetknięcie z ludnością wiejską jako społeczno-kulturowy i (w kontekście narodowo-politycznym) intencjonalny rozdźwięk ${ }^{68}$. Podczas gdy w części włoskiej to trydencki pomnik Dantego pełnił rolę lieu de memoire i cieszył się opinią must-see sight ${ }^{69}$, w niemieckojęzycznym Tyrolu do roli atrakcji turystycznej, wręcz turystycznego brand, awansowała przestrzeń wiejska — w szczególności ludność zamieszkująca góry ze swoimi tradycjami i praktykami. Stała się ona płaszczyzną różnorodnych projekcji, idealizujących wyobrażeń i heroizacji tego, co uważano za pradawne i bliskie korzeniom, co stanowiło o ludowej niezwykłości i specyficznej istocie, co narodowe (czczone np. w ludowym przedstawieniu Andreas Hofer Karla Wolfa [1848-1912], które wystawiane było w Meran i odniosło sukces).

Dla porównania można przyjrzeć się zakątkom południowo-wschodnim podwójnej monarchii, a mianowicie zróżnicowanemu etnicznie terenowi siedmiogrodzkich Karpat. Spojrzenie na tamten obszar uświadamia, że proces obciążania turystyki balastem nacjonalistycznym wiąże się w istotny sposób z istnieniem ukształtowanych społeczeństw mieszczańskich ${ }^{70}$. Jeśli w toku mise en tourisme

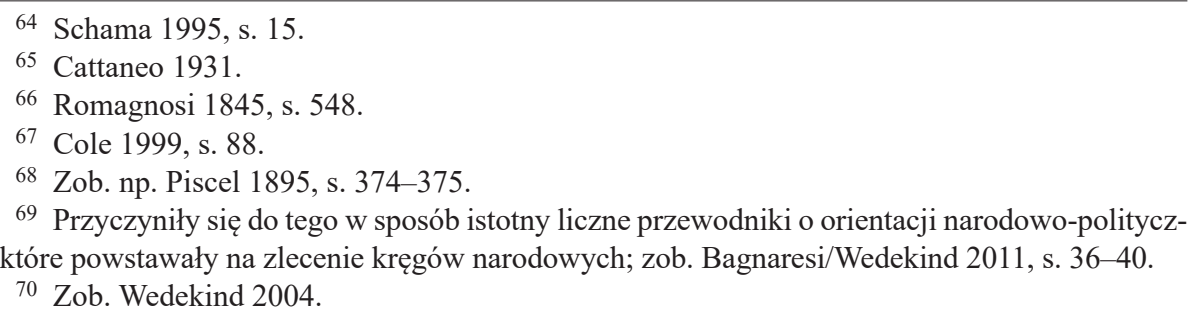


Karpat Wschodnich i Południowych konflikt dotyczył raczej odmiennych typów socjalizacji europejskiej ${ }^{71}$, a stojące naprzeciw siebie zetnicyzowane stanowiska dotyczące turystyki można odnotować późno i co najwyżej pomiędzy mieszczaństwem niemieckim i węgierskim (nie w odniesieniu do wąskich mieszczańskich kręgów Rumunów), to wydaje się, że musiały tu oddziaływać inne struktury społeczne niż na badanym obszarze Tyrolu. W Europie Środkowej we wzajemnej opozycji stały w związku z etnicyzacją turystyki ${ }^{72}$ odmienne projekty tożsamości, oferty integracji i mobilizacji, odmienne przypisywanie wartości przestrzeni i krajobrazowi tworzone przez konkurujące ze sobą, różniące się nastawieniem społeczeństwa mieszczańskie. Polityczna instrumentalizacja podróży otworzyła tam pole działania pojmowane przez niektórych jako laboratorium nacjonalizacji mas $^{73}$ oraz strategii segregacji etniczno-rasowej.

\section{Nad przepaścią}

Kiedy latem 1914 r. hotele nagle wyludniły się, również na dużym obszarze krajów alpejskich, spakowali walizki goście, którzy często mieli się już nie pojawić po zakończeniu pierwszej wojny światowej i wobec rosnącej demokratyzacji

${ }^{71}$ Odkrycie i objęcie w posiadanie wcześniej niemal niezauważanych terenów położonych wysoko w Karpatach przez mieszczaństwo siedmiogrodzko-saksońskie było wypadem w teren wcześniej już użytkowany i zamieszkiwany aż po wysokie partie, przede wszystkim przez pasterzy rumuńskich. Zanim rozpoczęło się estetyzowanie wysokich gór, niemieckie mieszczaństwo z Braşov trzymało się reguły, zgodnie z którą ,,włóczyć się po tych zatraconych górach wypadało tylko Wołochom" (Gusbeth 1912, s. 37). Później zaś Siedmiogrodzkie Towarzystwo Karpackie wciąż uskarżało się na niezgodne z przeznaczeniem wykorzystywanie, niszczenie i plądrowanie swoich schronisk przez rumuńskich pasterzy, którzy najwyraźniej postrzegali te budowle jako kulturowo obce ciała oraz semiotyczną afirmację egzogenicznych roszczeń terytorialnych. W tym względzie zmiana nastąpiła, gdy schroniska, których budowę towarzystwo uważało za „niemiecką pracę kulturotwórczą" (Bericht 1906, s. 72), zaczęły być poświęcane przez rumuńskich duchownych.

72 Należy w tym miejscu wspomnieć również inicjatywy, które nie podążyły za takimi wzorcami etnicyzacji. Należało do nich np. wydawane przez Adolfa Otto Schmalixa pomiędzy 1909 a 1913 w Brixen dwujęzyczne pismo „Adige ed Adria. Giornale illustrato forestieri — Etsch und Adria. Illustrierte Fremdenzeitung”, o którym De Gasperi powiedział w 1909 r.: „A noi più che la reclame descrittiva della nostra regione parve bello e degno della massima considerazione il compito che il signor Schmalix si proponeva, di rompere la diga di egoismo economico e le mura cinesi impastate di odio nazionale che la stampa e le associazioni tirolesi avevano eretto oltre Salorno". Schmalix był autorem licznych (częściowo ilustrowanych przez jego żonę, Idę von Lasser-Schmalix) przewodników po Południowym Tyrolu, Trydencie oraz po Dalmacji, ponadto właścicielem wydawnictwa przewodnikowego z siedzibą w Brixen i Monachium.

73 Przynależy tu m.in. włoska kampania „Difendiamo il Garda!!!”, która od 1909 r. była skierowana przeciwko dokonującej się rzekomo wokół turystyki germanizacji całego rejonu wokół jeziora Garda. Jako protagoniści występowali tu przede wszystkim irredentysta Scipio Sighele (1868-1913) i dziennikarz Luigi Federzoni (1878-1967), współzałożyciele Associazione Nazionalista Italiana, a później ministrowie pod rządami Benito Mussoliniego (1883-1945). Więcej o tym: Bagnaresi/Wedekind 2011, s. 41-51.

Góry, Literatura, Kultura 11, 2018

(C) for this edition by CNS 
podróżowania. Przystąpienie Włoch do wojny w niecały rok później uświadomiło „nawet najgłupszym, że skończyły się czasy letnich podróży do Tyrolu”74, jak napisał Walther Fournier (1870-1943), zamożny posiadacz ziem na wschód od Łaby i porucznik, któremu udało się zdać maturę dopiero po sześciokrotnej zmianie szkoły, a który w czasie wojny dawał upust swojej wybitnej pasji łowieckiej za liniami frontu, teraz zaś musiał ze względu na okoliczności zrezygnować $\mathrm{z}$ polowania na kozice $\mathrm{w}$ Tyrolu ${ }^{75}$. Wraz $\mathrm{z}$ utworzeniem frontu włoskiego na południowym zachodzie Monarchii Habsburskiej ten już wcześniej ,zaminowany" krajobraz wypoczynkowy stał się terenem starć militarnych przerastających dotychczasowe wyobrażenia. Wojna zmieniła obszar alpejski, tak jak i kulturę podróżowania po nim: zaprowadziła nowy porządek państwowo-terytorialny, etniczny i ekonomiczny ${ }^{76}$. Na niektórych obszarach spowodowała całkowite zniekształcenie (a zarazem zaostrzoną nacjonalizację) przyrody i krajobrazu. Skutkiem wojny było wykorzystanie do celów militarnych i zniszczenie infrastruktury turystycznej, a następnie postulaty dotyczące zmiany przeznaczenia budowli z militarnych na turystyczne. Wojna wzbudziła też chciwość wobec turystycznego potencjału przeciwnika ${ }^{77}$ i zradykalizowała raz jeszcze istniejące już nacjonalistyczne przypisania przestrzeni: wojna światowa stworzyła nowe narracje o Alpach, wystylizowała góry tu na „niemiecką świętość”, a tam na „ołtarz Włoch”. $\mathrm{Na}$ tle zinstrumentalizowanej politycznie żałoby i kultu zmarłych pojawiały się tutaj wołania o rewanż, tam o pośmiertne usprawiedliwienie udziału w wojnie wraz z monumentalną architektoniczną kulturą pamięci. To wszystko wpisywało się w zsakralizowany politycznie krajobraz oraz w kolektywną świadomość nowego narodowo-pielgrzymkowego nurtu turystów podążających na pola bitewne i do wojennych miejsc pamięci, na tereny, które odstąpiono bądź anektowano. We Włoszech już w 1919 r. można było nabyć pierwsze specjalne przewodniki prze-

74 Fournier 1917, s. 94.

75 Jak się to zachowało w jego (po części wydawanych pod pseudonimem „Dziki myśliwy”) relacjach z różnych pól wojennych i z niezliczonych polowań na ,„piękne [...] kobiety, potężne [...] jelenie i inną dziką zwierzynę”, bywalec Fournier korzystał z życia, również poza swoją egzystencją jako żołnierz i łowca. W czasie wojny światowej porucznik w sztabie wojsk lotniczych Fournier będący właścicielem ziemskim z wschodnio-brandenburskiego okręgu Crossen nad Odrą swoje dzieło Las, dzika zwierzyna, myślistwo poświęcił później ,„protektorowi niemieckiego lasu i niemieckiego polowania, premierowi Hermannowi Göringowi”. Zob. Fournier 1913; Fournier 1933; Tabel 2007, s. 222-238; jak i ogólnie w: Heymel 2007.

76 O ekonomicznych konsekwencjach pierwszej wojny światowej dla turystyki w regionie Trydentu zob. Bertoldi 1968.

77 Zob. np. Lanzerotti 1915; Sottochiesa 1917. Po administracyjnym rozwiązaniu trydenckiego Związku Alpejskiego DuÖAV już w roku 1915 planował rozdział schronisk SAT pomiędzy swoje własne sekcje: z 21 schronisk SAT 5 miało przypaść sekcji berlińskiej, 4 sekcji Trydent, 3 sekcji Brema, po 2 sekcjom Halle i Lipsk, a po jednym sekcjom Bamberg, Bozen, [Frankfurt-]Höchst, Norymberga, Überetsch i Wiedeń; zob. AÖAV: Obce związki — Società degli Alpinisti Tridentini. Z drugiej strony zaś CAI interweniowało w październiku 1916 r. u włoskiej administracji wojskowej, aby zapewnić sobie przekazanie własności tych schronisk DuÖAV, które leżały na terenach aneksyjnych przyznanych Włochom na mocy Traktatu Londyńskiego 1915; zob. Gibello 2011, s. 71.

Góry, Literatura, Kultura 11, 2018

(C) for this edition by CNS 
znaczone do tego celu ${ }^{78}$. Na obszarze niemieckim/austriackim podnosząca się dyskusja dotycząca ewentualnego zakazu podróży do utraconych prowincji szybko została zarzucona na rzecz znanej strategii narodowej mobilizacji podróżnych i host society Niemców z zagranicy; przewodniki i stosowne broszury wydawane przez organizacje narodowe i przez Związek Alpejski szybko zabrały głos, ogłaszając konstrukty związane z obcością oraz nawołując do gospodarczego bojkotu „obcych etnicznie"79. Przy tym elementy narodowe znalazły teraz, silniej niż przed wojną, wyraz w architekturze turystycznej: hotele, schroniska i budynki kolei linowych powstawały w pewnym sensie we wzajemnej opozycji, tu w duchu Razionalismo jako wyrazu ,italianita' oraz włosko-faszystowskich roszczeń władzy, tam zaś, z początku na bazie wzorców czerpanych ze stylu regionalnego, później po części w ściśle splecionym z ideologią narodowo-socjalistyczną stylu ojczyźnianym obszaru niemieckojęzycznego (i całego obszaru szwajcarskiego) ${ }^{80}$. Jednakże: turystyczne podróże we Wschodnie Alpy w okresie międzywojennym — słusznie to zauważono ${ }^{81}$ — nie odbywały się w żadnym razie wyłącznie pod znakiem politycznej retoryki i agitacji: tym, co znowu ciągnęło wielu w góry — także poza tradycyjnymi i nowymi formami wypoczynku i rozrywki (jak początki narciarstwa) - było wewnętrzne przezwyciężenie tragicznych przeżyć wojennych poprzez spotkanie z naturą.

Zjęzyka niemieckiego przełożyła Monika Witt

78 Notka bibliograficzna odnośnie do przewodników w: Wedekind 1994, s. 28-30.

79 Zob. Csaki 1932. Pochodzący z Sibiu (Rumunia) Richard Csaki (1886-1943) był w latach 1933-1941 kierownikiem Niemieckiego Instytutu Zagranicznego w Stuttgarcie.

${ }^{80}$ Do stylu ojczyźnianego odwoływali się też przedstawiciele (po części zbliżonego ideologicznie do państwa stanowego, po części heroicznie-patriotycznego) „modernizmu austriackiego”. Niektórzy z nich, jak Wilhelm Sachs (1884-1961), Clemens Holzmeister (1886-1983) czy Franz Baumann (1892-1974), wznosili jeszcze do ok. 1930 r. budynki hotelowe w Południowym Tyrolu.

81 Zob. odpowiednie uwagi w przejrzystym przyczynku Leoniego 1989, s. 22-23. 